\title{
MENDADAK E-LEARNING : \\ STUDI KUALITATIF MAHASASISWA PERGURUAN TINGGI SELAMA MASA PANDEMI COVI-19
}

\author{
Zobi Mazhabi ${ }^{1}$, Yoyok Amirudin ${ }^{2}$ \\ Universitas National Pingtung Taiwan \\ Email: aca109010@stamail.nptu.edu.tw ${ }^{1}$, aca109011@stamail.nptu.edu.tw ${ }^{2}$
}

Diterima: 11 Oktober 2021 I Direvisi: 23 November 2021 I Disetujui: 24 November 2021 (C)2021 Pendidikan Guru Raudhatul Atfhal Fakultas Agama Islam Universitas Islam Malang

\begin{abstract}
Pandemi Covid 19 membawa gangguan besar pada dunia pendidikan, memberikan tantangan baru bagi dunia pendidikan, dan membuat banyak stake holders lembaga pendidikan menjadi stres. Penelitian ini bertujuan untuk menganalisis persepsi mahasiswa terhadap peralihan pembelajaran offline ke pembelajaran online pada masa pandemi Covid 19. Penelitian ini dilakukan secara kualitatif melalui pelaksanaan wawancara prastruktur dengan melibatkan 35 mahasiswa yang tersebar di dua fakultas yang berbeda, enam jurusan yang berbeda, dan dipilih dari 245 mahasiswa. Wawancara dilakukan untuk mengumpulkan data dan untuk mendapatkan batasan persepsi dan pengalaman langsung dari mahasiswa yang menjadi salah satu bagian dari elemen utama masalah ini. Itu juga dilakukan berdasarkan pedoman yang dirancang oleh peneliti dan data yang dikumpulkan dianalisis dengan metode analisis isi dalam bentuk analisis isi deskriptif, analisis isi inferensial, analisis isi psikometrik, analisis isi prediktif. Temuan penelitian ini menunjukkan bahwa pembelajaran online selama pandemi Covid-19 memberikan kontribusi pengalaman positif dan pengalaman negatif kepada siswa baik dari segi unsur fisik, unsur psikologis, dan unsur kognitif. Temuan tersebut mengarah pada kesimpulan bahwa, dosen perlu melihat peluang, kelemahan, kekuatan, dan ancaman dari isu-isu yang bergeser ini untuk mendapatkan tindakan yang mungkin untuk pengembangan sistem pembelajaran online yang lebih baik.
\end{abstract}

Kata kunci: E-learning, kusempatan, tantangan

\begin{abstract}
The Covid 19 pandemic brings significant distruption to education, carrying out new challenge for education, and making alot of educational institutions stake holders becoming stressfull. This study aimed at analyzing the college students perception on
\end{abstract}

This work is licensed under Creative Commons Attribution Non Commercial 4.0 International License Available online on: http://riset.unisma.ac.id/index.php/fai/index 
shifting off line learning to online learning during Covid 19 pandemic . This study was conducted qualitatively through the implemetation of pre-structure interview by involving 35 student who spread in two different kinds of faculties, six different majors, and selected from 245 college students. The Interview was conducted to gather the data and to gain boundaries of direct perception and experiences belong to college students who became one part of primary element to this issue. It also was conducted based on the guidelines designed by the researchers and the data gathered analyzed with content analysis method in term of descriptive content analysis, inferential content analysis, psychometric content analysis, predictive content analysis. The findings of this research showed that on-line learning during Covid-19 pandemic contributed both of positive experience and negative experience to the students in term of physical element, psychological element, and cognitive element. The finding lead to the conclusion that, the lectures need to pretend to the opportunities, weaknesses, strength, and threats of this shifting issues in order to obtain the possible action for better development of the on-line learning system.

Key words: E-learning, Qualitative study, Opportunity, and Challenge

\section{A. Pendahuluan}

Merebaknya informasi akan bahayanya penularan Virus Corona pada awal Januari 2020 di China menjadi awal masifnya persebaran Virus jenis SARS-COV-2 di seluruh dunia. Hal ini dibuktikan degan adanya dua orang pasien yang terjangkit Virus Corona di Indonesia, sebagaimana yang telah di umumkan pemerintah pada tanggal 2 Maret 2020 (Kompas.com). Pengumuman terjangkitnya dua pasien ini telah menyebabkan perubahan yang signifikan di berbagai elemen dalam kehidupan masyarakat di Indonesia, lebih-lebih setelah di terapkannya kebijakan Pembatasan sosial bersekala besar (PSBB) hinga sampai pada kebijakan lock down. Salah satu bidang yang terkena dampaknya adalah bidang pendidikan di mulai dari jenjang pendidikan tingkat dasar hingga jenjang perguruan tinggi.

Sejumlah kebijakan yang telah di ambil di maksudkan untuk menjaga para guru, siswa, dan segenap unsur lembaga pendidikan seperti sekolah dan perguruan tinggi dari penularan virus corona dalam skala yang lebih besar dan masif. Dengan dibatasinya izin untuk melakukan interaksi sosial secara langsung dan berkerumunan dalam jumlah yang banyak maka dunia pendidikan mengalami peluang dan tantangan baru yang harus di pahami, di kalahkan, dan di manfaatkan untuk pengembangan pendidikan Indonesia ke depan. Sejalan dengan hal itu maka berdasarkan Surat Edaran Kementrian Pendidikan dan Kebudayaan No 4 tahun 2020 yang menjelaskan tentang bagaimana pendidkan harus dilaksanakan selama masa Pandemi Covid-19 (Pusdiklat, 2021), maka para guru dan dosen berinisiasi 
mengembangkan model pembelajaran secara on-line untuk masing-masing mata pelajaran atau mata kuliah yang sedang di ampunya pada saat itu.

Model pembelajaran online bagi mayoritas guru dan dosen adalah sesuatu yang masih jarang dilakukan karena selama ini tidak banyak guru dan dosen memanfaatkan model pembelajaran ini. Kramer mendefinisikan belejar on line atau distance learning sebagai sebuah sistem dan sebuah peroses yang menghubungkan pembelajar dengan berbagai macam sumber belajar atau referensi belajar dalam sebuah ruang elektronik yang sama tanpa ada penyempitan waktu (Kramer, 2021). Berdasarkan definisi ini para pembelajar tidak dibatasi oleh waktu dalam belajar, mereka dapat melakukan kegiatan belajar kapanpun dan dimanapun.

Supaya mampu melakukan pengembangan model pembelajaran yang efektif dan efisien, mapannya keilmuan pedagogis terkait hal itu dan memadainya teknologi berkenaan dengan hal tersebut, tidaklah cukup menjadi dasar bagi para pengajar dan pendidik untuk mengembangkan pembelajaran secara online (online learning), akan tetapi kita harus mengethui bagaiamana persepsi para mahasiswa yang menjadi objek dari kegiatan ini. Dalam temuan penelitiannya, Izzeidin (2021), menjelaskan bahwa pergeseran dari offline learning menuju ke online learning telah membantu mahasiswa melanjutkan peroses pembelajarannya, melatih para mahasiswa untuk lebih terlatih dengan kemampuan teknologi dalam bidang pendidikan, dan memperluas cakrawala informasi ilmu dan pengetahuan melalui informasi yang tersedia pada sejumlah website yang telah diberikan (Izzeidin, 2021). Sebaliknya, mereka juga berpendapat bahwa, jauh sebelumnya telah memaparkan bahwa selama pelaksanaan pembelajaran on-line di era pandemi 100 $\%$ mahasiswa merasa lelah, para mahasiwa mengalami sakit fisik, seperti sakit bahu, ganguan pandangan, dan sakit kepala, 98,6 \% memiliki manajemen waktu yang buruk, 68,6\% merasa terisolasi dari teman kelasnya, dan tentunya mengalami ketidak pastian akan penjelasan dosennya selama pembelajaran on-line berlangsung (Syahputri, 2021).

Adapun dalam penelitian ini, kami lebih berkonsentrasi mengali pengalaman yang di alami oleh para mahasiswa selama melaksanakan pembelajaran on-line melalui pendekatan teori analisis kebutuhan atau need analysis yang telah di jelaskan oleh Hutchinson (1987), meliputi framework analisa taraget kebutuhan pembelajaran yang bersifat pembelajaran yang dibutuhkan dan di inginkan (learning need and learning will), akan tetapi dalam pada penelitian ini akan kami kembangkan dalam enam cakupan besar yaitu peran dan fungsi media digital dalam pembelajaran secara on-line selama masa pandemi, pengalaman positif dan negatif selama tiga mingu pertama pergeseran pembelajaran menjadi online learning, tantangan yang di hadapi selama peroses pembelajaran, sejumlah aspek 
yang tidak bisa diperoleh karena adanya pergeseran model pembelajaran, sejumlah aspek yang harus di pelihara dan dikembangkan untuk pengembangan online learning ke depan, dan tantangan serta peluang dalam pembelajaran. Selain itu Dejene, W. (2020). Menjelaskan bahwa mayoritas guru terlebih khusus para guru pemula/praktikan (preservice teacher) menganut pendekatan-pendekatan tradisional dalam pembelajaran yang dilakukanya dari pada menegedepankan pendekatan konstruktivisme sehingga pembelajaran cenderung di pandang sebagai sebuah peroses transfer keilmuan yang berwujud persentasi atau mahasiswa sebagai objek pembelajaran bukan membentuk atau mengkonstruk desain pembelajaran yang disesuaikan dengan kondisi dan perubahan fenomena yang terjadi.

\section{B. Metode}

Karena telah terjadi pergeseran sistem pembelajaran dari sistem luring menuju kedaring maka dalam penelitian ini sangat menarik untuk mengetahui dan memahami pengalaman mahasiswa selama mengikuti pembelajaran. Pengalaman yang dimaksud berkaitan dengan apa saja yang mereka lakukan, alami dan rasakan selama mengikuti kegaiatan pembelajaran, oleh karena itu, pada penelitian kali ini, peneliti menggunakan metode penelitian qualitative dengan menerapakan wawancara pra terstruktur (pre-stucture interview) kepada 35 orang mahasiswa yang berasal dari dua fakultas yang berbeda (FAI Unisma dan Fakultas Ekonomi Unisma). Ke-35 mahasiswa ini tersebar dalam 6 jurusan yang berbeda dan tersebar di dalam tujuh rombel belajar yang berbeda sesuai dengan rombel belajar yang diatur oleh fakultas masing-masing serta di ambil 5 mahasiswa dari tujuh rombel yang tersedia. Adapun jumlah keseluruhan atau populasi dari penelitian ini adalah 245 mahasiswa dan dilakukan sampling secara acak dengan melibatkan 5 mahasiswa dari tiap-tiap rombel.

Interviev dilakukan karena peneliti ingin mengetahui pengalaman dan pandangan yang dirasakan langsung oleh salah satu elemen dari pelaksana pembelajaran on-line ini, sebagai mana dijelaskan Hutchinson (1987) bahwa Interview merupakan sebuah metode bertanya kepada partisipan atau sample pada penelitian ini untuk memberikan jawaban atas sejumlah pertanyaan yang di alamatkan kepadanya dengan cara merefleksi pada pengalaman yang mereka alami prihal topik yang di tanyakan dan pandangan mereka terhadap issue yang di tanyakan oleh interviewer dalam hal ini juga merupakan peneliti. (Thomson, 2017). Sementarai itu, untuk tahapan berikutnya wawancara pra terstruktur (Prestructured interview) dilakukan secara on-line dengan menggunakan sejumlah perangkat lunak pembelajaran daring seperti line dan google meet kemudian hasil interview di analisis dengan sistem analisa pendekatan sebagaimana telah di 
jelaskan oleh Neuendorf (2017) analisa isi meliputi analisa isi deskriptip, analisa isi infrensial, analisa isi psikometrik, dan analisa isi prediktif. Meskipun, interview dilakukan secara naratif akan tetapi, panduan interview atau interview guideline yang didesain oleh peneliti digunakan untuk memastikan sejumlah pertanyaan yang sama di alamatkan kepada 35 responden yang sudah terpilih dan mengontrol agar pertanyaan dan jawaban dalam interview yang dilakukan tidak keluar terlalu jauh dari guide line yang sudah di desain.

Secara keseluruhan, panduan wawancara atau Interview Guidelines yang telah didesain mencakup tiga sub kate-gori yaitu pergeseran penggunaan media belajar dari luring menuju ke daring dengan fokus pada kehidupan pribadi, perubahan pembelajaran di universitas, dan pandangan terhadap kondisi terkini universitas. Berikut sejumlah pertanyaan yang di alamatkan kepada para responden : (1) Peran apa yang telah di mainkan oleh media pembelajaran digital dalam pembelajaran jarak jauh anda?, (2) Tantangan apa yang telah anda hadapi, sedang anda hadapi, dan akan anda hadapi setelah mengikuti kegiatan pembelajaran dengan sistem daring atau E-learning selama tujuh kali tatap muka ini?, (3) Jelaskanlah sejumlah pengalaman yang anda dapatkan selama mengikuti kegiatan pembelajaran secara daring selama 7 minggu pertama ini (4) Apakah yang anda rindukan dan harapkan dalam pembelajaran secara jarak jauh? (5) Bila dibandingkan dengan pembelajaran sebelum datangnya pandemi dan ketika berlangsungya masa pandemi, apa yang berubah dalam pembelajaran anda jelaskan!, (5) Apakah anda ingin menyimpan materi yang diberikan selama pembelajaran jarak jauh?

Dikarenakan adanya pemberlakuan social distancing ber sekala besar, maka teknis pelaksanan interview dilakukan melalaui media zoom dalam tujuh glombang, setiap gelombang melibatkan lima orang mahasiswa yang terpilih dalam sampling yang telah dilakukan. Tidak hanya itu, peneliti juga meminta para responden untuk menuliskan beberapa jawaban dari pertanyaan yang tidak di sampaikan pada saat interview dalam bentuk tulisan. Selain dari pada itu, wawancara juga dilakukan melalui tempat masing-masing, sesuai dengan tempat domisisli para mahasiswa.

\section{Hasil dan Pembahasan}

Ketika interview di laksanakan, para responden telah melaksanakan pergeseran model belajar luring menuju ke online learning selama satu bulan. Hal ini menunjukan ingatan para responden masih segar akan pergeseran model belajar yang mereka alami di era pandemi ini, meskipun demikian, tidak ubahnya dosen yang memerlukan waktu untuk beradaftasi dengan situasi yang baru para mahasiswa yang dalam konteks ini juga merupakan responden dari penelitian ini, 
tentunya membutuhkan waktu untuk beradaftasi dengan sistem yang baru itu, agar capaian belajar mereka maximal.

\section{Peran dan Fungsi media digital dalam on-line learning}

Tidak ubahnya pembelajaran off line, pembelajaran dengan sistem on-line learning juga sangat membutuhkan pengembangan media pembelajaran yang akan membuat peroses belajar mengajar menjadi lebih menarik dan tidak membosankan serta konten pembelajaran akan terserap lebih mudah oleh para pembelajar. Hal ini dijelaskan oleh Liu bahwa penggunaan media digital akan menyebabkan pembelajaran menjadi lebih menarik dan menyenangkan bagi para pembelajar (Liu, 2016). Lebih-lebih hal ini telah ditegaskan sebelumnya oleh Gray (2010), bahwa pengembangan handphone sebagai salah satu media pembelajaran telah membuat lebih dari 50 \% partisipan dalam penelitian yang telah dilakukanya menyatakan bahwa ponsel meningkatkan tingkat keterlibatan pembelajar dalam proses belajar sangat signifikan, juga motivasi belajaranya. (Thomas, 2010). Selain itu juga Philipp Novikov menegaskan bahwa penggunaan media digital sebagai akibat dari peristiwa pergeseran off-line learning menuju ke on-line learning ini membuat peningkatan yang baik bagi kemampuan literasi komputer dan kemampuan kontrol diri para mahasiwa yang sangat memiliki peran yang sangat esensial dalam lingkungan belajar di eramoderen ini. (Novikop, 2020).

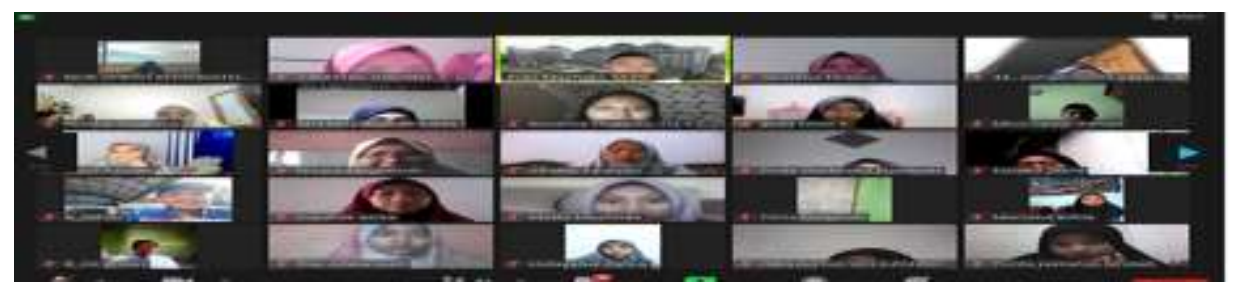

\section{Pengalaman pembelajaran on-line}

Pelaksanan pembelajaran on-line yang dilakukan dengan sistem interaksi sinkronus dan a-sinkronus baik menggunakan sejumlah media pembelajaran mutakhir seperti zoom google meet dan sejumlah sosial media seperti what'sup telah memberikan dampak yang cukup signifikan terhadap fisik dana psiskis psikologi para mahasiswa seperti kebosanan dan kesetresan akibat ketidak pastian dalam peroses belajar mengajar secara online sebagaimana di telah di ungkap oleh Andi Wahyu Irawan, Dwisona Dwisona, Mardi Lestari melalui penelitian qualitative penomenologi yang dilakukan di Universitas Mulawarman menunjukan bahwa efek dari pembelajaran secara online telah menyebabkan kebosanan, kecemasan, dan suasana hati yang tidak nyaman di benak para mahasiwa (Irawan, 2020). Pada saat yang bersamaan para mahasiwa juga mengalami keluhan fisik yang beragam seperti 
kelelahan, sakit kepala, demotivasi, merasa terisolasi, dan manajemen waktu yang buruk. Hal ini equivalen dengan temuan Wiles (2020), yang telah memaparkan bawa seseorang yang mengikuti pembelajaran secara on-line mengalami perubahan aktifitas lebih lama berada dilayar (screen) yang akan mengakibatkan tujuh perubahan besar dalam mental dan psikis mereka meliputi mengalami kelelahan yang tidak seperti biasanya, sakit kepala dan sejenisnya, kehilangan motivasi dalam mengerjakan tugas yang diberikan gurunya, kecenderungan menunda-nunda tugas, manajemen waktu yang tidak teratur, dan perasaan terisolasi karena jarang bertemu orang secara langsung (Mental Healt, 2021). Bila ditinjau dari sisi pelaksanaan, pelaksanaan pembelajaran on-line ini telah mempertajam gap pendidikan yang signifikan antara pembelajar yang berada di desa dan perkotaan atau dengan kata lain pembelajar yang memiliki latar belakang perekonomian yang cukup untuk memiliki perangkat pembelajaran on-line yang memadai dan sekelompok pembelajar yang tidak memiliki kemampuan untuk memeperoleh perangkat pembelajaran daring yang di butuhkan sebagaimana di tegaskan oleh Dube, B. (2020) bahwa selama Pandemi Covid-19 pembelajaran daring (on-line learning) menjadi satu-satunya solusi terbaik agar pembelajaran tetap dilakukan, seiring dengan berjalannya hal tersebut, maka hal ini menemukan beberapa kendala khususnya di daerah pedesaan seperti ketidak tersediaan jaringan internet, minimnya perangkat pembelajaran daring, ditutupnya warnet di pedesaan, mayoritas tenaga para pendidik yang belum bisa mengoprasikan perangat pembelajaran daring, dan paket data internet yang terbilang mahal.

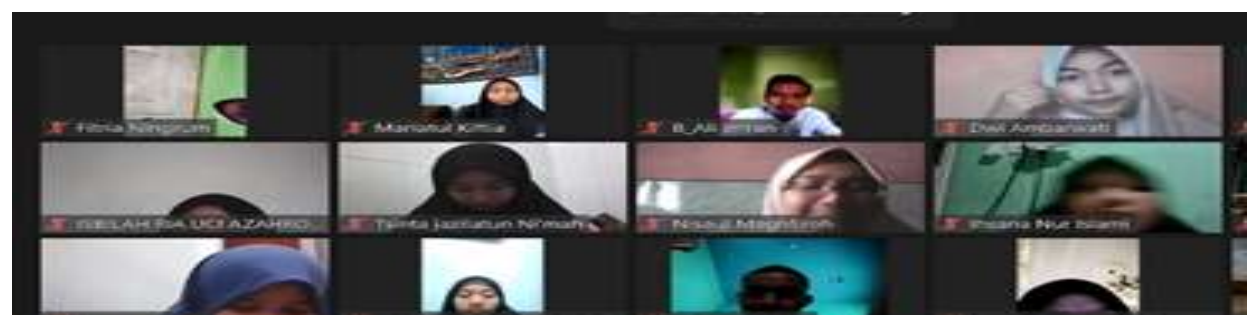

\section{On-line learning : Ancaman,Kerugian, Peluang dan Kesempatan}

Pada temuan penelitian ini berupaya menunjukkan dampak dari sejumlah permaslahan seperti metodologi teknologi dan psikologis yang di pakai dalam pembelajaran pasca transisi pembelajaran offline menuju online, khususnya pada kemampuan beradaptasi mahasiswa serta menawarkan wawasan tentang keuntungan dan kerugian yang dirasakan dari sistem serta peluang dan ancamannya baik dalam perspektif jangka pendek dan jangka panjang. Untuk mengklasifikasiakan variabel-variabel ini di deskripsikan dengan gambar, prinsipprinsip analisis kekuatan, kelemahan, ancaman dan peluang atau dengan penerapan 
analisis SWOT David (2017) diterapkan untuk membangun diagram peta pikiran SWOT (David, 2021), lihat Gambar 1:

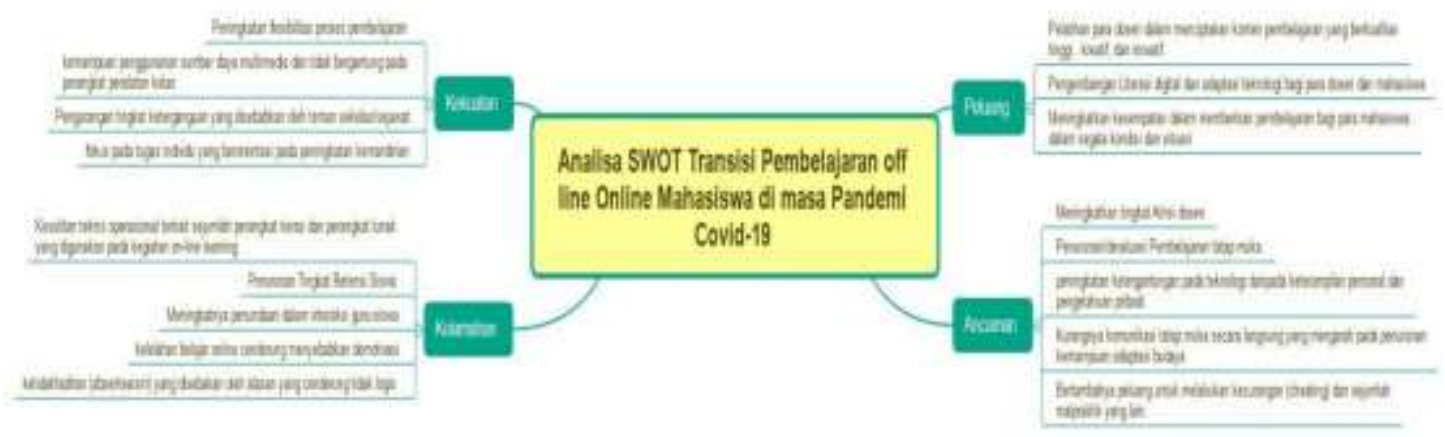

Gambar 1. Analisa SWOT Transisi Pembelajaran Offline-Online Mahasiswa di masa Pandemi COVID-19 (Sumber Data Penulis/interview bersama para responden).

Berdasarkan penjelassan David, Fred R \& David, Forest R berkenaan dengan langkah pelaksanaan analisa SWOT yang di mulai dari tahapan mendaftar key external factor yang berbentuk peluang (opportunity), kekuatan (strenght), ancaman (threats), dan weakneses (kelemahan), melakukan proses pencocokan (matching process) dari beberepa key extenal faktor yang telah di daftar untuk menghaasilkan beberapa strategi yang memungkinkan untuk dilakukang (resultant strategy) dalam menangani beberapa masalah yang muncul dalam pelaksanaan online learning di masa pandemi ini baik yang bersifat jangka panjang dan jangka pendek. Berikut peroses pencocokan masing-masing key external faktor serta formulasi strategi yang memungkinkan (resultant strategy) dalam tabel 1, 2, 3, dan 4 berikut ini.

Tabel 1. Pencocokan Kekuataan dan Peluang

\begin{tabular}{|l|l|l|}
\hline \multicolumn{1}{|c|}{ Kekuatan } & \multicolumn{1}{|c|}{ Peluang } & Strategi Yang dihasilkan \\
\hline $\begin{array}{l}\text { Peningkatan flexibilitas } \\
\text { proses pembelajaran }\end{array}$ & $\begin{array}{l}\text { Pelatihan para dosen dalam } \\
\text { menciptakan konten } \\
\text { pembelajaran yang } \\
\text { berkualitas tinggi , kreatif, } \\
\text { dan inovatif. }\end{array}$ & $\begin{array}{l}\text { Membangun dan } \\
\text { mengembangkan sistem } \\
\text { pembelajaran on line } \\
\text { yang sistematis, easy }\end{array}$ \\
\hline
\end{tabular}




\begin{tabular}{|l|l|l|}
\hline $\begin{array}{l}\text { kemampuan penggunanan } \\
\text { sumber daya multimedia dan } \\
\text { tidak bergantung pada } \\
\text { perangkat peralatan kelas }\end{array}$ & $\begin{array}{l}\text { Pengembangan Literasi } \\
\text { digital dan adaptasi teknologi } \\
\text { bagi para dosen dan } \\
\text { mahasiswa }\end{array}$ & $\begin{array}{l}\text { access, terukur, menarai, } \\
\text { kreaktif, dan inovatif }\end{array}$ \\
\hline $\begin{array}{l}\text { Pengurangan tingkat } \\
\text { keterganguan yang } \\
\text { disebabkan oleh teman } \\
\text { sekelas/sejawat }\end{array}$ & $\begin{array}{l}\text { Meningkatkan kesempatan } \\
\text { dalam memberikan } \\
\text { pembelajaran bagi para } \\
\text { mahasiswa dalam segala } \\
\text { kondisi dan situas }\end{array}$ & $\begin{array}{l}\text { Mengadakan Pelatihan } \\
\text { bagi para dosen untuk } \\
\text { mengelola dan } \\
\text { mengembangkan konten } \\
\text { pembelajaran on-line } \\
\text { yang telah di desain }\end{array}$ \\
\hline $\begin{array}{l}\text { fokus pada tugas individu } \\
\text { yang beroreintasi pada } \\
\text { peningkatan kemandirian }\end{array}$ & & \\
\hline
\end{tabular}

Tabel 2. Pencocokan Kelemahan dan Ancaman

\begin{tabular}{|c|c|c|}
\hline Kelemahan & Ancaman & Strategi Yang dihasilkan \\
\hline $\begin{array}{l}\text { Kesulitan teknis } \\
\text { operasional terkait } \\
\text { sejumlah perangkat keras } \\
\text { dan perangkat lunak yang } \\
\text { digunakan pada kegiatan } \\
\text { on-line learning }\end{array}$ & $\begin{array}{l}\text { Meningkatkan tingkat Atrisi } \\
\text { dosen }\end{array}$ & \multirow{2}{*}{$\begin{array}{l}\text { Membuka dan memfasilitasi } \\
\text { ruang kerjasama bagi para } \\
\text { dosen yang mengampu mata } \\
\text { kuliah yang sama dalam } \\
\text { mengembangkan konten } \\
\text { pembelajaran untuk } \\
\text { menghindari perbedaan input } \\
\text { yang akan diterimia } \\
\text { mahasiswa dan atrisi yang } \\
\text { tidak sehat antar dosen }\end{array}$} \\
\hline $\begin{array}{l}\text { Penurunan Tingkat } \\
\text { Retensi Siswa }\end{array}$ & $\begin{array}{l}\text { Penurunan/devaluasi } \\
\text { Pembelajaran tatap muka }\end{array}$ & \\
\hline $\begin{array}{l}\text { Meningkatnya penundaan } \\
\text { dalam interaksi guru- } \\
\text { siswa }\end{array}$ & $\begin{array}{l}\text { peningkatan } \\
\text { ketergantungan pada } \\
\text { teknologi daripada } \\
\text { keterampilan personal dan } \\
\text { pengetahuan pribadi }\end{array}$ & $\begin{array}{l}\text { Memngatur pelaksanaan } \\
\text { pembelajaran on-line agar } \\
\text { tidak } 100 / \% \text { online kelas } \\
\text { dengan cara memberikan } \\
\text { kegiatan-kegiatan lapangan } \\
\text { dan membangun dialog } \\
\text { interaktif di ruang zoominar } \\
\text { atau perangkat media beleajar } \\
\text { online yang lain }\end{array}$ \\
\hline $\begin{array}{l}\text { kelelahan belajar online } \\
\text { cenderung menyebabkan } \\
\text { demotivasi }\end{array}$ & $\begin{array}{l}\text { Kurangnya komunikasi } \\
\text { tatap muka secara langsung } \\
\text { yang mengarah pada } \\
\text { penurunan kemampuan } \\
\text { adaptasi budaya }\end{array}$ & \multirow{2}{*}{$\begin{array}{l}\text { Mendesain vaiasi kegiatan } \\
\text { pembelajaran agar } \\
\text { kegiatannya dapat bervariatif } \\
\text { seperti memberikan jam } \\
\text { istirahat selam } 10 \text { menit } \\
\text { setelah } 45 \text { menit pembelajarn } \\
\text { berlangsung. }\end{array}$} \\
\hline $\begin{array}{l}\text { ketidakhadiran } \\
\text { (absenteeism) yang } \\
\text { disebakan oleh alasan } \\
\text { yang cenderung tidak } \\
\text { logis }\end{array}$ & $\begin{array}{l}\text { Bertambahya peluang untuk } \\
\text { melakukan kecurangan } \\
\text { (cheating) dan sejumlah } \\
\text { malpraktik yang lain. }\end{array}$ & \\
\hline
\end{tabular}




\section{Simpulan}

Penelitian ini telah berupaya memberikan sejumlah data yang bersifat persepsi para mahasiswa sebagai akibat dari pergeseran offline learning menuju ke online learning, yang mencakup peran dan fungsi media digital dalam pelaksanaan on-line learning, pengalaman on-line learning para mahasiswa, dan On-line learning berkenaan dengan analisa ancaman,kerugian, peluang dan kesempatan, atau analisa SWOT , baik bersifat jangka panjang atau jangka pendek.

Selanjutnya, berdasarkan hasil analisa dari masing-masing cakupan ada sejumlah temuan penting yang perlu diperhatikan dalam upaya pengembangan pelaksanaan pembelajaran on-line pada tingkat mahasiswa kedepanya. Berangkat dari cakupan peran dan fungsi media digital dalam pembelajaran on-line, pengembangan konten konten belajar dalam bentuk media digital atau digitalisasi konten perkuliahan mutlak harus dilakukan oleh seluruh lembaga pendidikan terkhusus lembaga pendidikan tinggi demi terserapnya materia perkuliahan lebih mudah, tingkat aksessibilitas materi perkuliahan yang lebih mudah, dan mengurangi model pembelajaran persentasi menggunakan zoom yang akan mendatangkan kebosana bagi para mahasiswa. Pada cakupan kedua yang berkenaan dengan pengalaman belajar on-line selama masa pandemi, secara garis besar para mahasiswa mengalami pengalaman yang bersifat psikis dan fisik seperti kecapekan, sakit kepala, kebosanan, kesetresan akibat ketidak pastian dalam peroses belajar mengajar secara online. Sementara pada cakupan yang ketiga, Online learning berkenaan dengan analisa ancaman,kerugian, peluang dan kesempatan, atau analisa SWOT, baik bersifat jangka panjang atau jangka pendek. Para peneliti menemukan sejumlah peluang, kekuatan, kelemahan, dan ancaman dari pelalsanaan pembelajaran on-line di masa pandemi ini, tidak berhenti sampai tahap itu, diupayakan juga proses perumusan strategi yang mungkin dihasilkan (resultant strategy) dari display beberapa elemen dalam analisa SWOT yang dilakukan sehingga dihasilkan beberapa simpulam seperti pembangunan dan pengembangan on-line learning, digitalisasi konten materi perkuliahan, dan pelaksanaan pelatihan -pelatihan pengembangan pengeloalan on-line learning.

Penelitian ini memiliki beberapa keterbatasan. Kami harus mengatakan bahwa objek dalam penelitian ini hanya terbatas pada sejumlah mahasiswa yang terdapat pada satu universitas, tersebar di dalam beberapa fakultas. Penelitian lebih lanjut seharusnya dilaksanakan dengan lintasan studi yang beragam harus mempertimbangkan latar belakang sosial-budaya siswa, asal geografis, tingkat melek teknologi, usia, jenis kelamin. Pendekatan semacam itu akan membantu menyesuaikan pelatihan digital dalam keadaan darurat untuk para mahasiswa di universitas. Studi lebih lanjut juga harus mencakup tanggapan dari manajemen 
universitas dan staf akademik, dalam hal persepsi mereka tentang isu-isu yang harus diperhitungkan dalam pelaksanaan pembelajaran on-line selama masa pandemi ini.

\section{Daftar Rujukan}

Blended learning via distance in pre-registration nursing education: A scoping review. (2020). Nurse Education in Practice, 44 https://doi.org/ 10.1016/ j.nepr.2020.102775.

David, Fred R \& David, Forest R (2017) Strategic Management: A Competitive Advantage Approach Conept and Cases $16^{\text {th }}$ Edition. Pearson Education: United States of America.

Dejene, W. (2020). Conceptions of teaching \& learning and teaching approach preference: Their change through preservice teacher education program. CogentEducation, 7(1)http://dx.doi.org/10.1080/2331186X.2020. 1833812

Dube, B. (2020). Rural online learning in the context of COVID 19 in south africa: Evoking an inclusive education approach. REMIE Multidisciplinary Journal ofEducationalResearch, 10(2),135-157. :http://dx.doi.org/10.447/remie.2020.5607

Gray, L., Thomas, N., \& Lewis, L. (2010). Teachers' use of educational technology in USpublic schools: 2009 (NCES 2010-040). Washington, DC: National Center for Education Statistics, Institute of Education Sciences, U.S. Department of Education.

https://pusdiklat.kemdikbud.go.id/surat-edaran-mendikbud-no-4-tahun-2020-

tentang-pelaksanaan-kebijakan-pendidikan-dalam-masa-darurat-penyebarancorona-virus-disease-covid-1-9/ pada 21 Juli 2021.pukul. $09.02 \mathrm{am}$

https://www.kompas.com/sains/read/2020/05/11/130600623/diumumkanawal-maret-ahli--virus-corona-masuk-indonesia-darijanuari\#: :text=KOMPAS.com\%20\%2D\%20Pada\%202\%20Maret,ke\%20I ndonesia\%20sejak\%20awal\%20Januari. Pukul 07:29 am

Hutchinson, T., \& Waters, A. (1987). English for specific purposes: A learning-centred approach. Cambridge, England: Cambridge University Press.

Irawan, A. W., Dwisona, D., \& Lestari, M. (2020). Psychological Impacts of Students on Online Learning During the Pandemic COVID-19. KONSELI: Jurnal Bimbingan dan Konseling (E-Journal), 7(1),53-60.

Izzeidin. A \& B. Dair. RN (2021). Nursing Students And Faculty Members Perspective About Online Learning During Covid-19 Pandemic: A Qualitative Study, Teaching and Learning And Nursing Journal 13 (3) 1-7 https://doi.org/ 10.1016/j.teln.2021.02.008.

Kay, J., McRae, N., \& Leoni, R. (2020). Two institutional responses to work-integrated learning in a time of COVID-19: Canada and australia. International Journal of Work - Integrated Learning, 21(5), 491-503. https://www-proquest

Kelly, M. (2020). Languages and the coronavirus crisis. European Journal of Language Policy, 12(2), 257-270. 
Kramer. C (2001:23 ) Success in On-Line Learning. Thomson Learning. United States Of America. P. 23-24

Liu, P. (2016), "Technology integration in elementary classrooms: teaching practices of student teachers", Australian Journal of Teacher Education, Vol 41, No. 3, pp 87-104.Retrieved from: https://statenews.com/article /2020/07/students-share-impact-of-onlineclasses-

Neuendorf K. (2017). The Content Analysis Guide Book 2 ed., Los Angeles, London, New Delhi, Singapore, Wasighton Dc, Melbourne: Sage Publication. P. 71-80

Syahputri, V, N \& Parlindungan. F (2020) Online Learning drawbacks during the Covid-19 Pandemic: A pscychological Perspective, EnJourMe (English Journal of Merdeka): Culture, Language, and Teaching of English 5 (2) 109-116 https://doi.org/ 10.26905/enjourme.v5i2.5.

Thanyaphongphat, J. (2019). Effects of personalized learning with preferred digital media types on learning motivation. Kidmore End: Academic Conferences International Limited. http://dx.doi.10.34190/EEL.19.041

Thomson P. \& Hall C. (2017) Place-Based Methods For Researching Schools. New York: Blooms Burry Publishing Plc.

Wiles, G. (2020, July 30). Students share impact of online classes on their mental health. The State News.on-their-mental health?ct=content_open\&cv=cbox_latest. 